\title{
Residual Effect of Gypsum and Phosphate Fertilization on the Second Corn Crop
}

\author{
Héliton de Oliveira Resende ${ }^{1}$, Magno Gonçalves Braz ${ }^{1}$, Alex Oliveira Smaniotto ${ }^{1}$, Izamara Fonseca Tempesta ${ }^{1}$, \\ Claudio Hideo Martins da Costa $^{1} \&$ Simério Carlos Silva Cruz ${ }^{1}$ \\ ${ }^{1}$ Goiás Federal University, Jataí, Goiás, Brazil
}

Correspondence: Alex Oliveira Smaniotto, Goiás Federal University, Jataí, Goias, Brazil. Tel: 55-649-9613-5158. E-mail: aosmaniotto@gmail.com

Received: February 19, 2019

Accepted: March 29, 2019 Online Published: May 15, 2019

doi:10.5539/jas.v11n6p535

URL: https://doi.org/10.5539/jas.v11n6p535

\begin{abstract}
The objective of this study was to evaluate the residual effect of the gypsum when used with phosphate fertilization on the mineral nutrition, development and yield of second corn crop. The experiment was conducted at UFJ, with an experimental design consisting of 15 treatments established in randomized blocks in a $5 \times 3$ factorial scheme, with 4 replicates. The first factor corresponded to doses of gypsum $\left(0,1,2,4\right.$ and $\left.8 \mathrm{Mg} \mathrm{ha}^{-1}\right)$ and the second factor corresponded to doses of phosphorus $\left(0,40\right.$ and $\left.80 \mathrm{~kg} \mathrm{ha}^{-1}\right) .16$ months after the application of the various doses and treatments of agricultural gypsum, the following components were evaluated: dry root mass, macro and micronutrient contents in the leaves, production components and grain yield. The residual effect (16 months) of gypsum did not increase efficiency of phosphate fertilization for second corn crop. Under water stress conditions, the yield of corn grains responds to the application of agricultural gypsum above that of the dose recommended by the formula $\mathrm{NP}=5 \times \mathrm{g} \mathrm{kg}^{-1}$ of clay, which for this research is $2.93 \mathrm{Mg} \mathrm{ha}{ }^{-1}$ of gypsum. Phosphorus provides increases in corn grain yield only when $100 \%$ of the recommended dose is applied.
\end{abstract}

Keywords: Gypsum, phosphorus, soil, yield, Zea mays L.

\section{Introduction}

The cultivation of plants and the raising of livestock are complementary and elementary activities for the growth of a region. In this context, the corn crop (Zea mays) is of great importance. With this, the small crop or second corn crop of the year, known locally in Brazil as milho safrinha, which is sown from January to March, stands out as one of the main grain crops produced in Brazil, mainly in the South, Southeast and Center West, being sown immediately after the soybean harvest (CONAB, 2017).

Due to the time it is sown, the second corn crop often faces periods, sometimes long, of water stress. Therefore, the management of the soil in areas where the cultivation of this crop is common must provide optimum conditions for the full root development of corn, especially in terms of depth, since this practice will allow farmers to take advantage of a greater volume of soil, and consequently, a greater access to water and nutrients, focusing on those with low mobility or soil with the correct properties such as that with phosphorus (P), for example.

Among the main factors of the soil that limit the full development of the root system of agricultural crops are those of a physical nature, such as compaction, reduction of porosity and soil aeration, as well as those of a chemical nature, such as an excess of aluminum $\left(\mathrm{Al}^{3+}\right)$ and the low levels of calcium $\left(\mathrm{Ca}^{2+}\right)$ and $\mathrm{P}$ in subsurface.

Liming has long been the main tool for the correction of acidity and the supply of $\mathrm{Ca}^{2+}$ and $\mathrm{Mg}^{2+}$ to the soil, but in established no-till farming areas, the application of this corrective process is limited to the soil surface since excessive soil disturbance is avoided when liming. Thus, the benefits of liming are mostly restricted to the first few years and to the surface of soil, and therefore, does not solve the subsurface acidity problems.

Thus, the application of soil conditioners, such as agricultural gypsum, due to its greater solubility, reduces $\mathrm{Al}^{3+}$ activity and increases nutrient availability in the deeper layers of the soil (Ritchey, Silva, \& Costa, 1982). The combination of agricultural gypsum with liming may favor root development at greater soil depths, especially in 
areas under no-till farming, allowing for greater efficiency of water and nutrient absorption, as previously mentioned (Caires, Chueiri, Madruga, \& Figueiredo, 1998).

The edaphic conditions in which gypsum use is recommended are the following: $\mathrm{Ca}^{2+}$ content less than 0.5 cmolc $\mathrm{dm}^{-3}$, and saturation of $\mathrm{Al}^{3+}$ greater than $20 \%$ in the $20-40$ and $40-60 \mathrm{~cm}$ layers of soil (Sousa \& Lobato, 2004). However, the application of gypsum in soils where previously reported chemical conditions are not evident has been reported, in the literature, to have a positive effect on crops, especially corn (Maschietto, 2009).

As mentioned previously, in addition to $\mathrm{Ca}^{2+}, \mathrm{P}$ is a very important element for root development (Resende, Bustamante, Markewitz, Klink, \& Davidson, 2011); however, since tropical soils are naturally poor in nutrients, especially in $\mathrm{P}$, there wouldn't have been the remarkable performance in the production of grain, under the current Brazilian model of agriculture, without the addition of adaquate fertilizers, since they usually present low concentration of $\mathrm{P}$ and high power of "fixation" or "retention" of the P provided by fertilization (Eberhardt, Vendrame, Becquer, \& Guimarães, 2008).

There is a hypothesis that the greater development of the root system through the use of agricultural gypsum, often reported in the literature (Raij, 1988; Caires, Fonseca, Mendes, Chueiri, \& Madruga, 1999; Garbuio, 2006; Zandoná, Beutler, Burg, Barreto, \& Schmidt, 2015; Soares, 2016), can increase the absorption efficiency of P by the plants due to the greater volume of soil exploited by the plant, since this nutrient is practically immobile in soil.

The objective of this study was to evaluate the effect of phosphate fertilization under the residual effect (16 months) of agricultural gypsum on mineral nutrition, development and yield of second corn crop under no-till farming.

\section{Materials and Methods}

The experiment was conducted in the municipality of Jataí/GO, during the second corn crop of the agricultural year 2015/2016, in the experimental field of the Federal University of Jataí whose geographic coordinates are $17^{\circ} 55^{\prime} 32^{\prime \prime} \mathrm{S}$ and $51^{\circ} 42^{\prime} 32^{\prime \prime} \mathrm{W}$ at an altitude of $685 \mathrm{~m}$.

The predominant climate in the region is the Aw type, typical of savannas with two well defined seasons: one dry and cold (autumn and winter) and one hot and humid (spring and summer), according to the Köppen classification. The meteorological data measured during the experiment is presented in Figure 1.

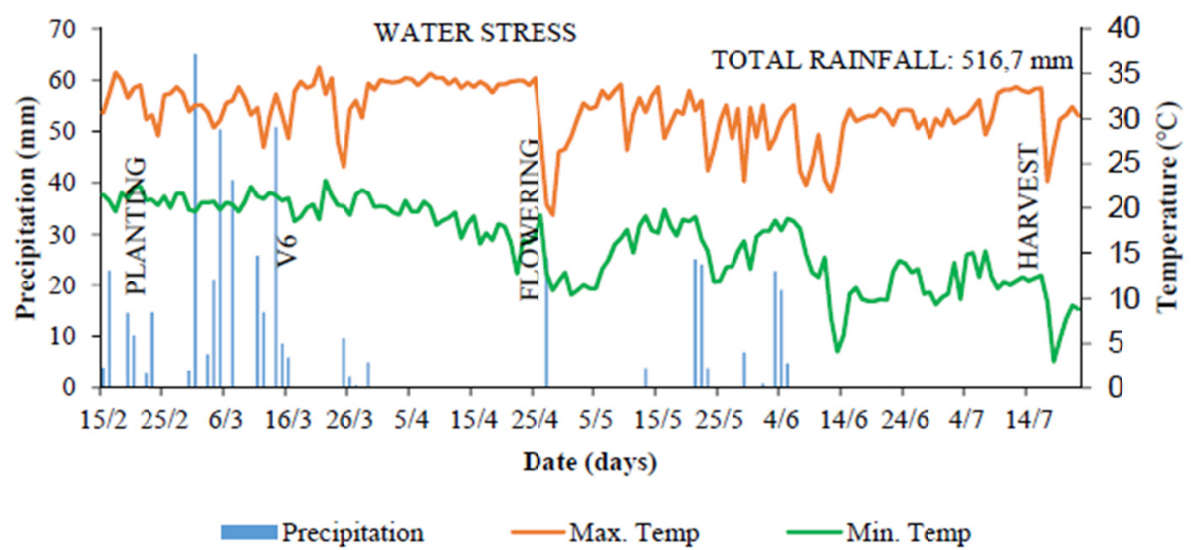

Figure 1. Rainfall $(\mathrm{mm})$, maximum and minimum temperatures $\left({ }^{\circ} \mathrm{C}\right)$, in the experimental area from February to July 2016

Source: INMET (2016).

The soil in the area was classified as dystroferric Red Latosol (LVdf), with a clay texture. Prior to the start of the research, the area had been cultivated for at least 10 years with soybean followed by corn or sorghum as a second crop using no-till farming and sometimes using simple superphosphate as the main source of phosphate fetilizer.

This research with its treatments (doses of gypsum and phosphorus) began during the first crop of 2014/2015 and is the only year in which gypsum was applied. Since then, the area has been cultivated in sequence with the following crops: soybean, second corn crop intercropped with brachiaria and soybean again. Therefore, 16 
months after the application of gypsum, the corn sown in the second crop of 2015/2016 was in fact the fifth crop cultivated.

The treatments related to $\mathrm{P}_{2} \mathrm{O}_{5}$ received fertilizers to increase productivity of soybean and second corn crop at their respective doses, which were 0,50 and $100 \%$ of the recommended dose of $\mathrm{P}_{2} \mathrm{O}_{5}$.

For the chemical and textural analysis of the soil before the research, 10 simple soil samples were collected, before the 2014/2015 harvest, with the aid of a probe to compose a composite soil sample of the soil layers 0-20 and 20-40 $\mathrm{cm}$ deep (Table 1).

Table 1. Chemical and textural analysis of the soil at 0-20 and 20-40 cm depths of the experimental area before carring out the experiment in 2014, Jataí, GO, 2018

\begin{tabular}{|c|c|c|c|c|c|c|c|c|c|c|}
\hline \multicolumn{11}{|c|}{ Porperties } \\
\hline Depth & $\mathrm{pH}$ & M.O. & P (mel.) & $\mathrm{K}$ & $\mathrm{Ca}$ & $\mathrm{Mg}$ & $\mathrm{Al}$ & $\mathrm{H}+\mathrm{Al}$ & CTC & $\mathrm{V} \%$ \\
\hline $\mathrm{cm}$ & $\left(\mathrm{H}_{2} \mathrm{O}\right)$ & $\mathrm{g} \mathrm{kg}^{-1}$ & $\mathrm{mg} \mathrm{dm} \mathrm{dm}^{-3}$ & \multicolumn{7}{|c|}{ - } \\
\hline $0-20$ & 5.7 & 45.2 & 8.5 & 0.16 & 2.26 & 1.37 & 0.10 & 5.1 & 8.9 & 42.6 \\
\hline $20-40$ & 5.8 & 36.1 & 4.3 & 0.13 & 1.75 & 0.95 & 0.07 & 4.3 & 7.1 & 39.9 \\
\hline
\end{tabular}

Since it is an experiment in which the effects of the treatments have been evaluated over time since the beginning of the first crop of the agricultural year of 2014/2015 and that the chemical analysis of the soil is always carried out after the harvest of the second corn crop, the soil's chemical analysis performed after the harvest of the second crop of the year of 2015 have also been presented in table 2 for a better explanation of the data.

The values of the chemical components in Table 2 are presented per plot according to the chemical changes occurring in the soil after the first application of the treatments (doses of gypsum and phosphorus). As $P$ levels in the soil showed no response in the first year after application (year prior to this experiment), the mean values of $\mathrm{P}\left(\mathrm{Mehilch}^{-1}\right)$ of treatments which received different doses of $\mathrm{P}_{2} \mathrm{O}_{5}$ were taken into account (Table 2).

Table 2. Chemical and textural analysis of the soil in the $0-20$ and $20-40 \mathrm{~cm}$ layers of the experimental plots sampled after the harvest of the second corn crop in 2015, Jataí, GO, 2018

\begin{tabular}{|c|c|c|c|c|c|c|c|c|}
\hline \multirow{2}{*}{ Soil Layer } & \multirow{2}{*}{ Gypsum } & \multirow{2}{*}{$\mathrm{pH} \mathrm{H} \mathrm{H}_{2} \mathrm{O}$} & \multirow{2}{*}{$\mathrm{H}^{+}+\mathrm{Al}^{3+}$} & \multicolumn{5}{|c|}{ Exchangeable cation } \\
\hline & & & & $\mathrm{Al}^{3+}$ & $\mathrm{Ca}^{2+}$ & $\mathrm{Mg}^{2+}$ & $\mathrm{K}^{+}$ & $\mathrm{P}\left(\right.$ Mehilch $\left.^{-1}\right)$ \\
\hline $\mathrm{cm}$ & $\mathrm{Mg} \mathrm{ha}^{-1}$ & & ----י & - & $\mathrm{cmol}_{\mathrm{c}} / \mathrm{s}$ & - & 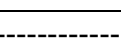 & $\mathrm{mg} \mathrm{dm}^{-3}$ \\
\hline \multirow[t]{5}{*}{$0-20$} & 0 & 6.08 & 6.79 & 0.03 & 3.28 & 1.55 & 0.15 & 16.18 \\
\hline & 1 & 6.23 & 6.10 & 0.03 & 3.86 & 1.53 & 0.14 & 14.00 \\
\hline & 2 & 6.02 & 6.50 & 0.03 & 3.84 & 0.96 & 0.11 & 15.59 \\
\hline & 4 & 5.93 & 6.67 & 0.03 & 4.29 & 0.65 & 0.11 & 18.83 \\
\hline & 8 & 5.89 & 6.26 & 0.01 & 4.95 & 0.42 & 0.13 & 20.19 \\
\hline \multirow[t]{5}{*}{$20-40$} & 0 & 5.60 & 6.86 & 0.06 & 1.86 & 0.76 & 0.10 & 4.04 \\
\hline & 1 & 5.68 & 6.39 & 0.02 & 2.14 & 0.77 & 0.10 & 3.59 \\
\hline & 2 & 5.58 & 6.41 & 0.04 & 2.11 & 0.68 & 0.08 & 3.35 \\
\hline & 4 & 5.52 & 6.53 & 0.02 & 2.62 & 0.58 & 0.07 & 4.73 \\
\hline & 8 & 5.50 & 6.33 & 0.03 & 3.54 & 0.35 & 0.08 & 5.79 \\
\hline Sand & Silt & Clay & & & & & & \\
\hline \multicolumn{9}{|c|}{ 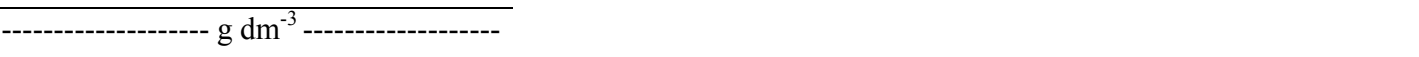 } \\
\hline 585 & 240 & 175 & & & & & & \\
\hline
\end{tabular}

Note. Modified by Soares (2016).

The experimental design consisted of 15 treatments established in randomized blocks, in a $5 \times 3$ factorial scheme, with four replications, with each plot measuring $11.25 \mathrm{~m}^{2}(2.25 \times 5 \mathrm{~m})$. The first factor corresponded to the doses of gypsum $\left(0,1,2,4\right.$ and $\left.8 \mathrm{Mg} \mathrm{ha}^{-1}\right)$, and these doses represent $0,34,68,136$ and $273 \%$ of the 
recommended dose according to Sousa and Lobato (2004). The second factor corresponded to the doses of phosphorus $\left(0,40\right.$ and $80 \mathrm{~kg} \mathrm{ha}^{-1}$ of $\left.\mathrm{P}_{2} \mathrm{O}_{5}\right)$ representing 0,50 and $100 \%$ of the recommended dose.

For soil correction $3.0 \mathrm{Mg} \mathrm{ha}^{-1}$ of dolomitic limestone (85\% PRNT) was applied relying soley on gravity to penetrate the soil 3 months before sowing the soybean crop in the agricultural year of 2014/2015. The gypsum was applied only once 30 days after the limestone in each treatment's respective doses and since then the area had been cultivated every year with a rotation of soybean and corn intercropped with brachiaria. Only the residual effect of the applied gypsum in a combination with phosphate fertilization was evaluated from the first year being carried out at the time of sowing of each crop in all agricultural years. The chemical makeup of the gypsum used in this research is shown in Table 3.

Table 3. Chemical composition and moisture of the agricultural gypsum used in the experiment. Jataí, GO, 2018

\begin{tabular}{llllllllll}
\hline Gypsum Characteristics & $\mathbf{C a}$ & $\mathbf{S}$ & Total Humidity & Humidity (65 $\mathbf{~}^{\circ}$ & $\mathbf{P}_{\mathbf{2}} \mathbf{O}_{\mathbf{5}}$ & $\mathbf{C u}$ & $\mathbf{F e}$ & $\mathbf{M n}$ & $\mathbf{Z n}$ \\
\hline $\mathbf{( \% )}$ & 23.56 & 18.64 & 25.22 & 21.74 & 0.67 & 0.014 & 0.25 & 0.012 & 0.005 \\
\hline
\end{tabular}

The recommended doses of N, P and $\mathrm{K}$ for a high yield of corn were $150 \mathrm{~kg} \mathrm{ha}^{-1}$ of N and $80 \mathrm{~kg} \mathrm{ha}^{-1}$ of $\mathrm{P}_{2} \mathrm{O}_{5}$ and $\mathrm{K}_{2} \mathrm{O}$. The sources used were urea, triple superphosphate and potassium chloride, respectively. The $\mathrm{P}_{2} \mathrm{O}_{5}$ was distributed at sowing time in the furrow at the doses for each treatment. It is important to note that for the crops prior to the second corn crop the same doses of $\mathrm{P}_{2} \mathrm{O}_{5}$ were used. $\mathrm{N}$ and $\mathrm{K}$ were manually distributed in each plot. For $\mathrm{N}$, the applied urea doses were $30 \mathrm{~kg} \mathrm{ha}^{-1}$ at sowing and $120 \mathrm{~kg} \mathrm{ha}^{-1}$ when the crop was at the V3-V4 stage. The first and second applications of $\mathrm{K}_{2} \mathrm{O}$ were carried out at 15 and 25 days after sowing with doses of 60 and 20 $\mathrm{kg} \mathrm{ha}^{-1}$ of $\mathrm{K}_{2} \mathrm{O}$, respectively.

The sowing of the hybrid corn AG-8677 PRO 2 was carried out on February 23, 2016, using a 5 row planter tractor distributing 2.8 seeds per meter. Each plot was composed of 5 rows of 5 meters, the area of use being the 3 center rows with $0.50 \mathrm{~m}$ excluded from each end. Corn seeds were treated industrially with deltamethrin.

With the objective of controlling invasive plants, a dose $1.5 \mathrm{~L} \mathrm{ha}^{-1}$ of commercial atrazine and $1.5 \mathrm{~L} \mathrm{ha}^{-1}$ commercial glyphosate was applied during the V3-V4 stage. In order to control Spodoptera frugiperda (fall armyworm), two applications were made with the products Bulldock ${ }^{\circledR} 125$ SC (beta-cyfluthrin) and Connect ${ }^{\circledR}$ (imidacloprid and beta-cyfluthrin), with $0.1 \mathrm{~L} \mathrm{ha}^{-1}$ and $0.75 \mathrm{~L} \mathrm{ha}^{-1}$, respectively.

Weed management was performed with a post-emergence application of $2.5 \mathrm{~L}$ of glyphosate and $1.5 \mathrm{~L}$ of atrazine $\mathrm{ha}^{-1}$ for the control of unwanted soybean plants. Two preventive applications of fungicides with the product Approach Prima $\left(0.3 \mathrm{~L} \mathrm{ha}^{-1}\right)$ were applied for disease management. Pest control was performed with insecticide based on the level of weed control in the area using the products Bulldock $125 \mathrm{SC}\left(0.1 \mathrm{~L} \mathrm{ha}^{-1}\right)$ and Connect $\left(0.75 \mathrm{~L} \mathrm{ha}^{-1}\right)$.

At the time of the female inflorescence (silking), 5 leaves were collected per plot, opposite and below the first ear, excluding the central vein, to determine macro and micronutrient leaf contents according to Martinez et al. (1999). The leaves were kept in an oven at $60^{\circ} \mathrm{C}$ until it had a constant mass. The dry leaves were then sent to the Laboratory of Analysis of Soils and Vegetable Tissue of the State University Paulista (UNESP) "Júlio de Mesquita Filho" Ilha Solteira Campus for determination of macro and micronutrient contents according to methodology described by Malavolta et al. (1997).

Root samples were collected before harvesting the corn, where three soil samples were collected, randomly distributed within the area of use of each plot in the middle of the betweenlines, that is, $22.5 \mathrm{~cm}$ away from the planting lines, in the soil layers $0-20$ and $20-40 \mathrm{~cm}$ in depth. For this operation, a probe was used which is capable of collecting a volume of 0.922 liters of soil for every $20 \mathrm{~cm}$ of depth. After the collection, with the aid of a sieve and running water, the soil and roots present in the sample were separated.

Subsequent to the separation, the collected root samples were left in a forced air circulation oven at $60{ }^{\circ} \mathrm{C}$ until the plant material had a constant mass, to be weighed to quantify the mass of dry roots in each plot. Subsequently, the dry root mass values obtained were corrected to a standard volume of $1.0 \mathrm{dm}-3$ of the initial soil sample.

At harvest time (07/13/2016), the ears present in the area of use of each plot were collected manually and stored in bags with the identification of their respective plots. Ten ears were randomly assigned to each plot to determine the dry mass of the ear, the number of rows of grain per ear, the length of the ear, the diameter of the ear, as well as, the diameter of the cobs. By subtracting the last two parameters and then dividing the result by two the average grain length was calculated. 
Then, the ears were harvested together along with the others for grain sorting where they quantified their mass for calculating the grain yield per plot. Which was later transformed into $\mathrm{kg} \mathrm{ha}^{-1}$ of grains with moisture corrected to $13 \%$. For the determination of the mass of one thousand grains, the moisture was corrected to $13 \%$ and determined according to the methodology described in Brazil (2009).

The data was submitted to variance analysis at $5 \%$ and/or $1 \%$ of probability using the $\mathrm{F}$ test, and when only 3 levels were presented the means of data referring to the doses of $\mathrm{P}$ when significant to the $\mathrm{F}$ test were compared by the Tukey test. To present more than three levels of data concerning gypsum doses when significant to the $\mathrm{F}$ test, the data was submitted to the regression analysis calculated for linear and quadratic equations and accepted when significant up to $5 \%$ of probability by the $\mathrm{F}$ test. For this, the statistical program Assistat 7.7 was used (Silva \& Azevedo, 2016).

\section{Results and Discussion}

The summary of the variance analysis (F-Test) for foliar macronutrient content in the studied corn hybrid is shown in Table 4. It was observed that there was no interaction between the studied factors for any of the foliar macronutrient content studied. There was significant effect only for gypsum variation for the foliar content of $\mathrm{Ca}^{2+}$ and $\mathrm{Mg}^{2+}$ (Table 4). The mean values of the $\mathrm{Ca}^{2+}$ foliar content were adjusted to the positive linear regression equation according to the increasing doses of gypsum (Figure 2).

Table 4. Summary of variance analysis (Test F) for: block, gypsum, phosphorus and their interactions for the foliar macronutrient contents in corn.

\begin{tabular}{lllllll}
\hline Variation Causes & $\mathrm{N}$ & $\mathrm{P}$ & $\mathrm{K}$ & $\mathrm{Ca}$ & $\mathrm{Mg}$ & $\mathrm{S}$ \\
\hline Block & $0.72^{\mathrm{ns}}$ & $8.28^{* *}$ & $5.23^{*}$ & $1.44^{\mathrm{ns}}$ & $2.16^{\mathrm{ns}}$ & $2.16^{\mathrm{ns}}$ \\
Gypsum (G) & $1.07^{--}$ & $0.68^{--}$ & $1.28^{--}$ & $4.59^{--}$ & $2.05^{--}$ & $0.99^{--}$ \\
Phosphorus (P) & $0.04^{\mathrm{ns}}$ & $0.30^{\mathrm{ns}}$ & $0.13^{\mathrm{ns}}$ & $0.77^{\mathrm{ns}}$ & $1.16^{\mathrm{ns}}$ & $1.08^{\mathrm{ns}}$ \\
$\mathrm{G} \times \mathrm{P}$ & $0.79^{\mathrm{ns}}$ & $1.18^{\mathrm{ns}}$ & $0.88^{\mathrm{ns}}$ & $1.26^{\mathrm{ns}}$ & $1.23^{\mathrm{ns}}$ & $0.98^{\mathrm{ns}}$ \\
\hline Polynomial Regression & & & & & \\
\hline Linear Reg. & $1.02^{\mathrm{ns}}$ & $0.25^{\mathrm{ns}}$ & $0.68^{\mathrm{ns}}$ & $12.00^{* *}$ & $2.92^{\mathrm{ns}}$ & $0.20^{\mathrm{ns}}$ \\
Quadratic Reg. & $0.01^{\mathrm{ns}}$ & $1.99^{\mathrm{ns}}$ & $2.11^{\mathrm{ns}}$ & $1.74^{\mathrm{ns}}$ & $5.18^{*}$ & $2.36^{\mathrm{ns}}$ \\
\hline
\end{tabular}

Note. Polynomial Regression. ${ }^{* *}$ significant at $1 \%$ probability $(\mathrm{p}<0.01) .{ }^{*}$ significant at $5 \%$ probability $(0.01 \leq \mathrm{p}$ $<0.05)$. ns not significant $(\mathrm{p} \geq 0.05)$.

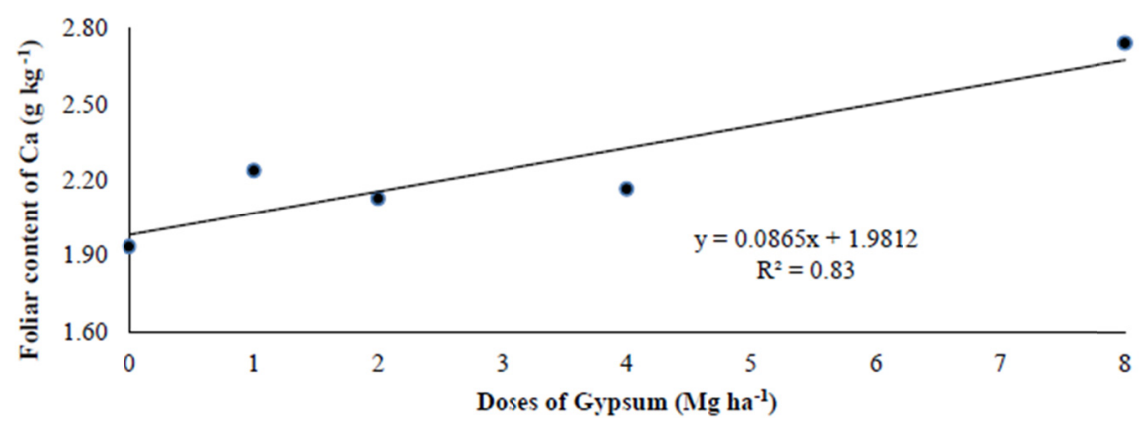

Figure 2. $\mathrm{Ca}^{2+}$ foliar content of corn crop due to doses of gypsum

Similar results were observed by Soares (2016) and (Caires, Blum, Barth, Garbuio, \& Kusman, 2003), who verified a linear increase in $\mathrm{Ca}^{2+}$ concentrations in soybean foliar tissue, with the applied gypsum doses, and by (Caires, Garbuio, Churka, \& Joris, 2011), who observed a positive effect of the gypsum on the $\mathrm{Ca}^{2+}$ foliar content in corn.

For the $\mathrm{Mg}^{2+}$ macronutrient content, the means were better fitted to the quadratic regression equation as a function of the gypsum doses, as can be observed in Figure 3. After deriving the quadratic equation, the highest leaf content of $\mathrm{Mg}^{2+}$ of $2.32 \mathrm{~g} \mathrm{~kg}^{-1}$ was obtained by using $2.22 \mathrm{Mg} \mathrm{ha}^{-1}$ of gypsum. This decrease in $\mathrm{Mg}^{2+}$ foliar content due to the use of gypsum above $2.22 \mathrm{Mg} \mathrm{ha}^{-1}$ can be explained by the reduction of $\mathrm{Mg}^{2+}$ in all the layers of soil. This is because, the application of gypsum in high doses can cause the movement of exchangeable 
cations in the soil profile, leading Mg to move deeper through the soil, which results in the plant absorbing less of the nutrient and thus having less concentration of the nutrient in the leaf (Rampin, Lana, Frandoloso, \& Fontaniva, 2011).

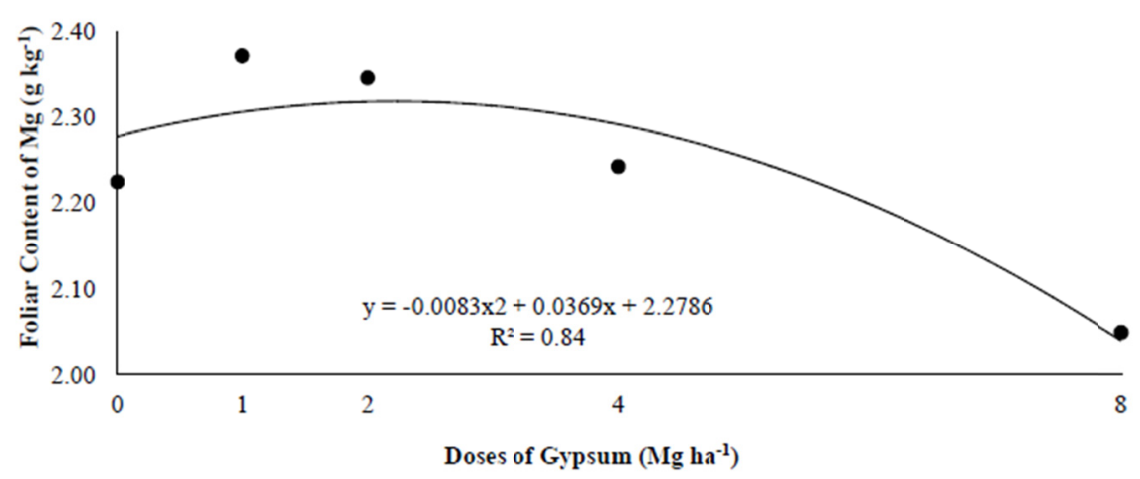

Figure $3 . \mathrm{Mg}^{2+}$ foliar content of corn crop as a function of gypsum doses

Caires, Kusman, Barth, Garbuio, and Padilha (2004) and Raij et al. (1998) also found a decrease in the Mg foliar content in corn due to gypsum. This reduction of $\mathrm{Mg}$ in corn due to high doses of gypsum shows that leaching of exchangeable $\mathrm{Mg}$ in the soil related to the use of large amounts of gypsum can impair the absorption of the nutrient by plants. In the literature there are also reports of the same thing having occurred in soybean crops (Glycine max) (Oliveira \& Pavan, 1996; Caires et al., 1998; 1999).

Other factors may also influence the decrease of $\mathrm{Mg}^{2+}$ content through the use of gypsum. The Ca:Mg ratio is antagonistic, that is, the increase in the concentration of an ion causes a generally partial and reversible decrease in the absorption of another element, which combines to the carrier to cross the membrane in the same way (Malavolta, 2006; Prado, 2008). The absence of a response in the foliar content of $\mathrm{P}$ as a function of phosphate fertilization (Table 4) can be explained by the fact that water stress occurs when the second harvest corn crop is in most need of water.

The summary of the variance analysis (Test F) for the foliar content of micronutrients and crude protein (PB\%) in the studied corn hybrid is shown in Table 5. It was observed that there was no interaction between the factors for any of the studied variables. By evaluating in isolation the dose variations of $\mathrm{P}_{2} \mathrm{O}_{5}$, it was verified that there was no significance for any of the foliar micronutrient content studied (Table 5).

Table 5. Summary of the variance analysis (F test) for: block, gypsum, phosphorus and their interactions for the micronutrients: zinc $(\mathrm{Zn})$, manganese $(\mathrm{Mn})$, iron $(\mathrm{Fe})$ copper $(\mathrm{Cu})$ and crude protein $(\mathrm{PB} \%)$ of the foliar analysis, determined at the full flowering stage of the corn crop

\begin{tabular}{llllll}
\hline Variation Causes & $\mathrm{Zn}$ & $\mathrm{Mn}$ & $\mathrm{Fe}$ & $\mathrm{Cu}$ & $\mathrm{PB} \%$ \\
\hline Block & $10.19^{* *}$ & $9.42^{* *}$ & $1.60^{\mathrm{ns}}$ & $6.71^{* *}$ & $0.72^{\mathrm{ns}}$ \\
Gypsum (G) & $2.64^{--}$ & $0.60^{--}$ & $1.57^{--}$ & $1.63^{--}$ & $1.07^{--}$ \\
Phosphorus (P) & $1.03^{\mathrm{ns}}$ & $0.12^{\mathrm{ns}}$ & $1.00^{\mathrm{ns}}$ & $1.14^{\mathrm{ns}}$ & $0.04^{\mathrm{ns}}$ \\
$\mathrm{G} \times \mathrm{P}$ & $2.21^{\mathrm{ns}}$ & $1.09^{\mathrm{ns}}$ & $1.15^{\mathrm{ns}}$ & $0.23^{\mathrm{ns}}$ & $0.79^{\mathrm{ns}}$ \\
\hline Polinomail Regression & & & & $0.43^{\mathrm{ns}}$ & $1.02^{\mathrm{ns}}$ \\
\hline Linear Reg. & $10.33^{* *}$ & $0.49^{\mathrm{ns}}$ & $0.51^{\mathrm{ns}}$ & $2.83^{\mathrm{ns}}$ & $0.01^{\mathrm{ns}}$ \\
Quadratic Reg. & $0.25^{\mathrm{ns}}$ & $1.25^{\mathrm{ns}}$ & $5.01^{\mathrm{ns}}$ &
\end{tabular}

Note. ${ }^{--}$Polinomial Regression. F Test does not apply. ${ }^{* *}$ significant at $1 \%$ probability $(\mathrm{p}<0.01) .{ }^{*}$ significant at $5 \%$ probability $(0.01 \leq \mathrm{p}<0.05)$. ${ }^{\text {ns }}$ not significant $(\mathrm{p} \geq 0.05)$.

When evaluating the dose variations of gypsum in isolation, there was only significance for the $\mathrm{Zn}^{2+}$ foliar content, adjusting the negative linear regression equation (Figure 4), that is, there was a reduction of $\mathrm{Zn}^{2+}$ foliar content as a function of increasing the doses of gypsum. This result can be explained by the increase in the $\mathrm{Ca}^{2+}$ 
foliar content due to the increasing doses of gypsum (Figure 2), since high levels of $\mathrm{Ca}^{2+}$ in the soil provide an inhibitory effect for the absorption of $\mathrm{Zn}^{2+}$ (Malavolta, 2006).

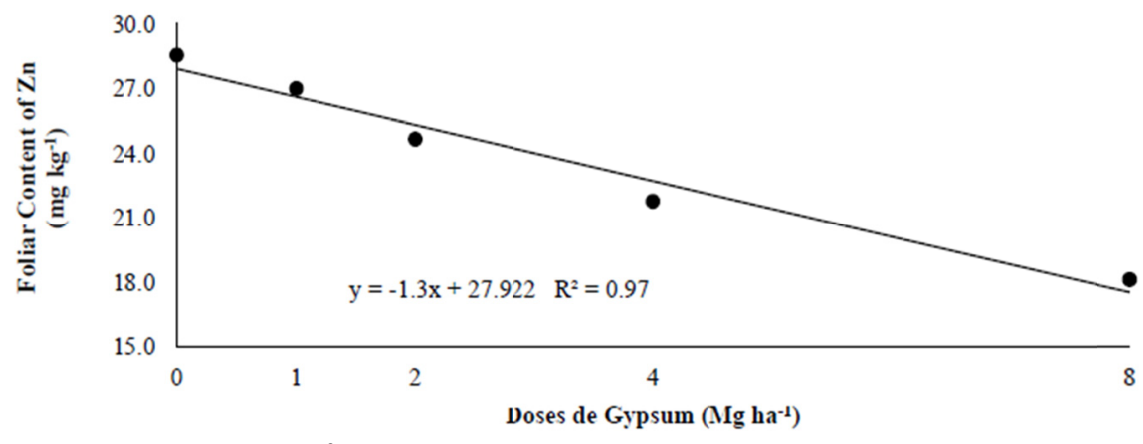

Figure 4. $\mathrm{Zn}^{2+}$ leaf content of corn crop due to gypsum doses

The variance analysis (F-test) of the dry root mass of the studied corn (DRM) in the 0-20 and 20-40 cm soil layers is shown in Table 6. It can be observed that there was interaction between the studied factors only in the 20-40 cm layer of soil. The corn DRM averages were not altered with the applied gypsum doses for any soil layer studied.

Table 6. Summary of variance analysis (Test F) for: block, gypsum, phosphorus and their interactions for dry root mass (DRM)

\begin{tabular}{lll}
\hline \multirow{2}{*}{ Variance Causes } & \multicolumn{2}{c}{ DRM } \\
\cline { 2 - 3 } & $0-20 \mathrm{~cm}$ & $20-40 \mathrm{~cm}$ \\
\hline Block & $2.26^{\mathrm{ns}}$ & $0.36^{\mathrm{ns}}$ \\
Gypsum (G) & $0.72^{--}$ & $0.66^{--}$ \\
Phosphorus (P) & $3.23^{*}$ & $1.54^{\mathrm{ns}}$ \\
$\mathrm{G} \times \mathrm{P}$ & $1.42^{\mathrm{ns}}$ & $0.90^{*}$ \\
\hline Polinomial Regression & & $0.73^{\mathrm{ns}}$ \\
\hline Linear Reg. & $0.04^{\mathrm{ns}}$ & $0.18^{\mathrm{ns}}$ \\
Quadratic Reg. & $2.79^{\mathrm{ns}}$ & ${ }^{*}$ \\
\hline
\end{tabular}

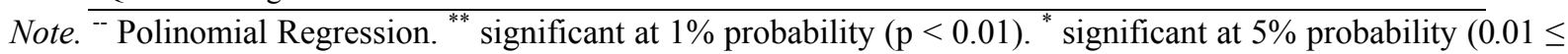
$\mathrm{p}<0.05)$. ${ }^{\mathrm{ns}}$ not significant $(\mathrm{p} \geq 0.05)$.

Evaluating, in isolation, the doses of $\mathrm{P}$, only the dry roots mass in the $0-20 \mathrm{~cm}$ layer of soil presented different results among the evaluated doses (Table 7). As $\mathrm{P}_{2} \mathrm{O}_{5}$ doses increased, there was a reduction in dry root mass, where plants grown in plots that received $80 \mathrm{~kg} \mathrm{ha}^{-1}$ of $\mathrm{P}_{2} \mathrm{O}_{5}$ showed a reduction in root mass when compared to plants that did not receive phosphate fertilization.

The low values of DRM obtained possibly occurred due to modifications in root growth and architecture since they are variables that directly interfere in the DRM. Which were pointed out by several authors as a response to low availability of $\mathrm{P}$ (Alves et al., 2002).

Table 7. Dry root mass (DRM) of corn in the $0-20 \mathrm{~cm}$ layer of soil when evaluating the phosphorus doses in isolation

\begin{tabular}{ll}
\hline Doses of $\mathrm{P}_{2} \mathrm{O}_{5}\left(\mathrm{~kg} \mathrm{ha}^{-1}\right)$ & DRM $\left(\mathrm{g} \mathrm{dm}^{-3}\right)$ \\
\hline 0 & $8.31 \mathrm{a}$ \\
40 & $7.89 \mathrm{ab}$ \\
80 & $7.01 \mathrm{~b}$ \\
$\mathrm{CV} \%$ & 21.93 \\
\hline
\end{tabular}

Note. The averages followed by the same letter do not differ statistically from each other, according to the Tukey test at $5 \%$ probability. 
Pereira (2007), evaluating the DRM in many soil layers noted that in the presence of gypsum the dry root mass values tend to decrease in the $0-10 \mathrm{~cm}$ layer of soil and increase in layers deeper than $10 \mathrm{~cm}$. Different results were found by Rosolem e Marcello (1998), who observed that the low availability of P, induces root growth in terms of length with a consequent increase in surface area of the root, but without increasing dry root mass.

In the interaction between gypsum and phosphorus there was an increase in the dry root mass of corn with the increase in the availability of $\mathrm{P}$ only in the 20 to $40 \mathrm{~cm}$ layer of soil and only for the dose of $8,0 \mathrm{Mg} \mathrm{ha}^{-1}$ of gypsum (Table 8).

Table 8 . The result of the interaction between gypsum and phosphorus for the dry root mass of corn of the 20-40 cm layer

\begin{tabular}{llllll}
\hline \multirow{2}{*}{$\mathrm{P}_{2} \mathrm{O}_{5}$ doses $\left(\mathrm{kg} \mathrm{ha}^{-1}\right)$} & \multicolumn{5}{c}{ Gypsum doses $\left(\mathrm{Mg} \mathrm{ha}^{-1}\right)$} \\
\cline { 2 - 5 } & 0 & 1 & 2 & 4 & 8 \\
\hline & $--1.23 \mathrm{a}$ & $4.44 \mathrm{a}$ & $4.20 \mathrm{a}$ & $3.87 \mathrm{a}$ & $3.63 \mathrm{~b}$ \\
40 & $4.65 \mathrm{a}$ & $4.25 \mathrm{a}$ & $4.70 \mathrm{a}$ & $3.49 \mathrm{a}$ & $3.66 \mathrm{~b}$ \\
80 & $3.84 \mathrm{a}$ & $4.46 \mathrm{a}$ & $4.06 \mathrm{a}$ & $4.22 \mathrm{a}$ & $5.25 \mathrm{a}$ \\
$\mathrm{CV} \%$ & 16.29 & & & \\
\hline
\end{tabular}

Note. The averages followed by the same letter in the column do not differ statistically from each other. The Tukey test was applied at 5\% probability.

The summary of the variance analysis (F-Test) for corn production components is shown in Table 9. There was no interaction between the factors studied $(\mathrm{G} \times \mathrm{P})$ for any of the evaluated production components. For the $\mathrm{P}_{2} \mathrm{O}_{5}$ dose variation factor, only ear diameter and number of rows presented different behavior out of the doses evaluated (Table 9).

For ear diameter, the treatment that did not receive phosphate fertilization presented lower values in relation to the others. For the number of rows per ear, there was a significant difference only between treatments 0 and 80 $\mathrm{kg} \mathrm{ha}^{-1}$ of $\mathrm{P}_{2} \mathrm{O}_{5}$ (Table 10). These components exhibit a relationship of dependency with each other, since the increase in the number of rows usually results in ears with larger diameter.

Table 9. Summary of variance analysis (Test F) for: block, gypsum, phosphorus and their interactions for the production components in corn

\begin{tabular}{lllllll}
\hline Variation Causes & Ear Diameter & Cob Diameter & Grain Length & Ear Length & Number of Rows & 1000 Grains \\
\hline Block & $2.09^{\mathrm{ns}}$ & $2.88^{*}$ & $11.79^{* *}$ & $4.68^{* *}$ & $0.71^{\mathrm{ns}}$ & $12.67^{* *}$ \\
Gypsum (G) & $0.85^{--}$ & $0.26^{--}$ & $0.25^{--}$ & $1.52^{--}$ & $1.64^{--}$ & $0.81^{--}$ \\
Phosphorus (P) & $4.22^{*}$ & $1.29^{\mathrm{ns}}$ & $2.37^{\mathrm{ns}}$ & $1.84^{\mathrm{ns}}$ & $3.32^{*}$ & $1.36^{\mathrm{ns}}$ \\
$\mathrm{G} \times \mathrm{P}$ & $0.40^{\mathrm{ns}}$ & $0.32^{\mathrm{ns}}$ & $0.38^{\mathrm{ns}}$ & $0.54^{\mathrm{ns}}$ & $0.72^{\mathrm{ns}}$ & $0.44^{\mathrm{ns}}$ \\
\hline Polinomial Regression & & & & & & \\
\hline Linear Reg. & $0.13^{\mathrm{ns}}$ & $0.21^{\mathrm{ns}}$ & $0.64^{\mathrm{ns}}$ & $0.36^{\mathrm{ns}}$ & $0.50^{\mathrm{ns}}$ & $0.41^{\mathrm{ns}}$ \\
Quadratic Reg. & $2.24^{\mathrm{ns}}$ & $0.16^{\mathrm{ns}}$ & $0.32^{\mathrm{ns}}$ & $5.46^{*}$ & $2.76^{\mathrm{ns}}$ & $2.22^{\mathrm{ns}}$ \\
\hline
\end{tabular}

Note. ${ }^{--}$Polinomial Regression. ${ }^{* *}$ significant at $1 \%$ probability $(\mathrm{p}<0.01) .{ }^{*}$ significant at $5 \%$ probability $(0.01 \leq$ $\mathrm{p}<0.05) .{ }^{\mathrm{ns}}$ not significant $(\mathrm{p} \geq 0.05)$.

Table 10. Average ear diameter, number of rows and productivity, evaluating the doses of phosphorus in isolation

\begin{tabular}{lll}
\hline Doses of $\mathrm{P}_{2} \mathrm{O}_{5}\left(\mathrm{~kg} \mathrm{ha}^{-1}\right)$ & Ear Diameter $(\mathrm{cm})$ & Number of Rows (un) \\
\hline 0 & $4.46 \mathrm{~b}$ & $14.27 \mathrm{~b}$ \\
40 & $4.56 \mathrm{a}$ & $14.39 \mathrm{ab}$ \\
80 & $4.56 \mathrm{a}$ & $14.64 \mathrm{a}$ \\
\hline $\mathrm{CV} \%$ & 2.96 & 2.93 \\
\hline
\end{tabular}

Note. The averages followed by the same letter do not differ statistically from each other using the Tukey test at $5 \%$ probability. 
The increase in ear diameter and number of rows per ear, provided by the treatments with phosphorus, is due to the higher demand for this nutrient during the V6 stage, which positively affects with the number of grain rows in the V8 stage, length of ears in the V12 stage and consequently in productivity (Fancelli \& Dourado Neto, 2000).

Evaluating, in isolation, the dose variations of gypsum (Table 9), there was only significance for the the length of ear component. It is noteworthy that the averages adjusted better to the quadratic regression equation model due to the increase of the gypsum doses (Figure 5), where the highest ear length of $14.01 \mathrm{~cm}$ was obtained with application of $3.28 \mathrm{Mg} \mathrm{ha}^{-1}$ of gypsum.

Amaral et al. (2017) evaluating the length of corn ears cultivated in the second harvest crop observed an increase due to increasing doses of gypsum $\left(0,1,2,3\right.$ and $\left.4 \mathrm{Mg} \mathrm{ha}^{-1}\right)$, which obtained the highest values of ear length at the dose of $4 \mathrm{Mg} \mathrm{ha}^{-1}$. A different result was obtained by Soares (2016), who did not observe any effect of agricultural gypsum on the length of ears from the second corn crop, however for this author rainfall distribution was abundant and uniform during the conduction of the experiment.

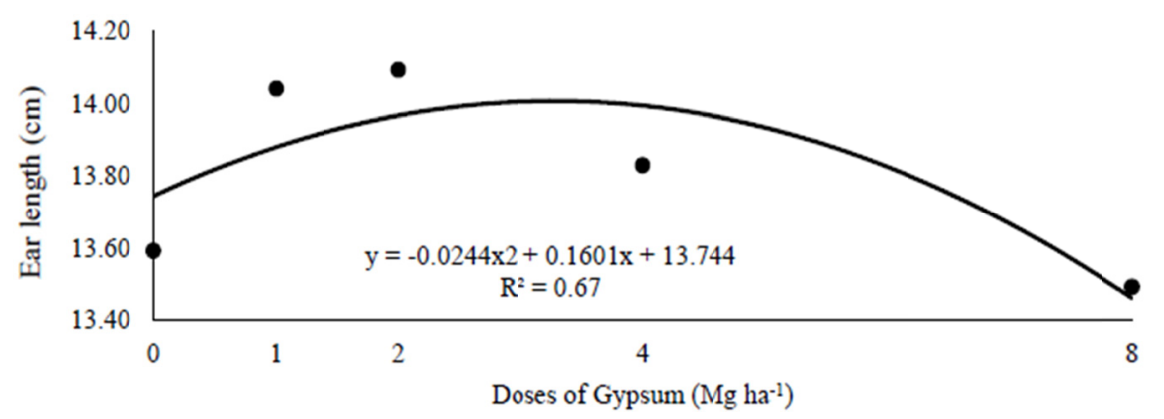

Figure 5. Ear length of the corn crop due to doses of agricultural gypsum

The summary of the variance analysis (Test F) for corn grain yield is shown in Table 11. There was no interaction between the different sources studied. However, it is possible to notice that there was an isolated significant effect for the doses of gypsum and P.

Table 11. Summary of variance analysis (Test F) for: block, gypsum, phosphorus and their interactions for corn grain yield

\begin{tabular}{ll}
\hline Causes of Variance & Produtivity $\left(\mathrm{kg} \mathrm{ha}^{-1}\right)$ \\
\hline Block & $2.39^{\mathrm{ns}}$ \\
Gypsum (G) & $4.34^{--}$ \\
Phosphorous (P) & $4.05^{*}$ \\
$\mathrm{G} \times \mathrm{P}$ & $2.10^{\mathrm{ns}}$ \\
\hline Polinomial Regression & \\
\hline Linear Reg. & $3.00^{\mathrm{ns}}$ \\
Quadratic Reg. & $10.86^{* *}$ \\
\hline
\end{tabular}

Note. ${ }^{--}$Polinomial Regression. ${ }^{* *}$ significant at $1 \%$ probability $(\mathrm{p}<0.01) .{ }^{*}$ significant at $5 \%$ probability $(0.01 \leq$ $\mathrm{p}<0.05) .{ }^{\text {ns }}$ not significant $(\mathrm{p} \geq 0.05)$.

Evaluating, in isolation, the $\mathrm{P}_{2} \mathrm{O}_{5}$ values against productivity, (Table 12), as well as, the two production components mentioned in Table 10, showed that there are increases in productivity due to the availability of $\mathrm{P}$ because of fertilization. The treatment that received $80 \mathrm{~kg} \mathrm{ha}^{-1}$ of $\mathrm{P}_{2} \mathrm{O}_{5}$, was superior to the treatment with no phosphate fertilization (Table 12). These results can be explained by the increases observed in ear diameter and number of rows (Table 10), since both add to yield. 
Table 12. Corn grain yield, with the variation factor $\mathrm{P}$ evaluated in isolation

\begin{tabular}{ll}
\hline Doses of $\mathrm{P}_{2} \mathrm{O}_{5}\left(\mathrm{~kg} \mathrm{ha}^{-1}\right)$ & Produtivity $\left(\mathrm{kg} \mathrm{ha}^{-1}\right)$ \\
\hline 0 & $1778.56 \mathrm{~b}$ \\
40 & $1886.44 \mathrm{ab}$ \\
80 & $1935.49 \mathrm{a}$ \\
\hline $\mathrm{CV} \%$ & 9.56
\end{tabular}

Note. The averages followed by the same letter do not differ statistically from each other using the Tukey test at $5 \%$ probability.

Evaluating, in isolation, the grain productivity against the various gypsum doses, there is adjustment to the quadratic equation model as a function of the gypsum doses (Figure 6), where maximum productivity was obtained, 2,054.9 $\mathrm{kg} \mathrm{ha}^{-1}$, with an application of $4.38 \mathrm{Mg} \mathrm{ha}^{-1}$ of gypsum. Under conditions of water stress, as in this study, the corn grain yield responded to the application of agricultural gypsum beyond the dose recommended by the formula $\mathrm{NG}=5 \times \mathrm{g} \mathrm{kg}^{-1}$ of clay, which for this study is $2.93 \mathrm{Mg} \mathrm{ha}^{-1}$ of gypsum.

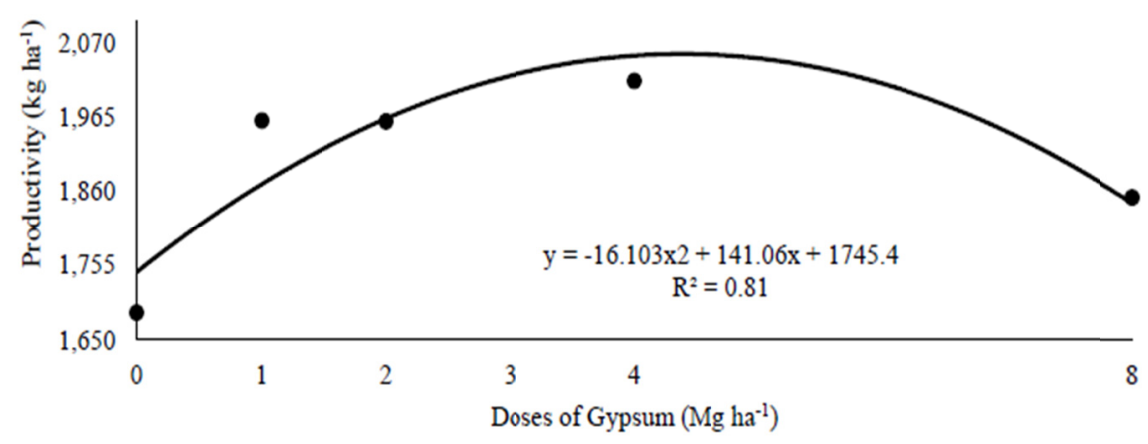

Figure 6. Corn productivity due to gypsum doses

The low yields of second corn crop found in this study are due to the long period of water stress, totaling 65 days with accumulated rainfall of $46.1 \mathrm{~mm}$ between the V6 and grain fill stages (Figure 1). Soares (2016) did not observe an effect of the agricultural gypsum on the soybean crop and the second harvest corn, in a year of good rainfall, unlike Amaral et al. (2017), which in the absence of water stress, observed in a test also conducted in Dystroferric Red Latosol during a year of good rainfall, evaluating the yield of corn grown in the second crop with increasing doses of gypsum $\left(0,1,2,3\right.$ and $\left.4 \mathrm{Mg} \mathrm{ha}^{-1}\right)$ observed a linear increase in productivity, with a productivity of $6480 \mathrm{~kg} \mathrm{ha}^{-1}$ at a dose of $4 \mathrm{Mg} \mathrm{ha}^{-1}$.

Sousa, Lobato, and Rein (2005), observed the highest corn yield of $5525 \mathrm{~kg} \mathrm{ha}^{-1}$ at the dose of $1 \mathrm{t} \mathrm{ha}^{-1}$ of gypsum, while Caires et al. (2004) found a higher increase in yield with $9 \mathrm{t} \mathrm{ha}^{-1}$ of gypsum in a Dystrophic Red Latosol (cited by Amaral et al., 2017).

\section{Conclusion}

The residual effect of the gypsum (16 months after its application) does not provide an increase in the efficiency of phosphate fertilization for the second corn crop.

Under water stress conditions, the yield of corn grains responds well to the application of agricultural gypsum above that of the recommended dose of the formula $\mathrm{NG}=5 \times \mathrm{g} \mathrm{kg}^{-1}$ of clay, which for this research is $2.93 \mathrm{Mg}$ $\mathrm{ha}^{-1}$ of gypsum.

Phosphorus provides increases in corn grain yield only when $100 \%$ of the recommended dose is applied $(80 \mathrm{~kg}$ $\mathrm{ha}^{-1}$ of $\mathrm{P}_{2} \mathrm{O}_{5}$ ).

\section{References}

Alves, V. M. C., Parentoni, S. N., Vasconcellos, C. A., Pitta, G. V. E., \& França, C. C. M. (2002). Cinética de absorção de fósforo e crescimento do sistema radicular de genótipos de milho contrastantes para eficiência a fósforo. Revista Brasileira de Milho e Sorgo, 1, 85-92. https://doi.org/10.18512/1980-6477/rbms. v1n1p85-92 
Amaral, L. A., Ascari1, J. P., Duarte, W. M., Mendes, I. R. N., Santos, E. S., \& Julio, O. L. L. (2017). Efeito de doses de gesso agrícola na cultura do milho e alterações químicas no solo. Revista Agrarian, 10, 31-41. https://doi.org/10.30612/agrarian.v10i35.4139

Brasil. (2009). Regras para análise de sementes: Secretaria de Defesa Agropecuária. Ministério da Agricultura, Pecuária e Abastecimento.

Caires, E. F., Blum, J., Barth, G., Garbuio. F. J., \& Kusman, M. T. (2003). Alterações químicas do solo e resposta da soja ao calcário e gesso aplicados na implantação do sistema plantio direto. Revista Brasileira de Ciência do Solo, 27, 275-286. https://doi.org/10.1590/S0100-06832003000200008

Caires, E. F., Chueiri, W. A., Madruga, E. F., \& Figueiredo, A. (1998). Alterações de características químicas do solo e resposta da soja ao calcário e gesso aplicados na superfície em sistema de cultivo sem preparo do solo. Revista Brasileira de Ciência do Solo, 22, 27-34. https://doi.org/10.1590/S0100-06831998000100004

Caires, E. F., Fonseca, A. F., Mendes, J., Chueiri, W. A., \& Madruga, E. F. (1999). Produção de milho, trigo e soja em função das alterações das características químicas do solo pela aplicação de calcário e gesso na superfície, em sistema de plantio direto. Revista Brasileira de Ciência do Solo, 23, 315-327. https://doi.org/10.1590/S0100-06831999000200016

Caires, E. F., Garbuio, F. J., Churka, S., \& Joris, H. A. W. (2011). Use of gypsum for crop grain production under a subtropical no-till cropping system. Agronomy Journal, 103, 1804-1814. https://doi.org/10.2134/ agronj2011.0192

Caires, E. F., Kusman, M. T., Barth, G., Garbuio, F. J., \& Padilha, J. M. (2004). Alterações químicas do solo e resposta do milho à calagem e aplicação de gesso. Revista Brasileira de Ciência do Solo, 28, 125-136. https://doi.org/10.1590/S0100-06832004000100013

CONAB (Companhia Nacional de Abastecimento). (2017). Acompanhamento da safra brasileira de grãos, $12^{\circ}$ Levantamento setembro/2017. Retrieved from http://www.conab.gov.br/conteudos.php? $\mathrm{a}=1253 \& \mathrm{t}=$

Eberhardt, D. N., Vendrame, P. R. S., Becquer, T., \& Guimarães, M. F. (2008). Influência da granulometria e da mineralogia sobre a retenção do fósforo em Latossolos sob pastagens no cerrado. Revista Brasileira de Ciência do Solo, 32, 1009-1016. https://doi.org/10.1590/S0100-06832008000300010

Fancelli, A. L., \& Dourado-Neto, D. (2000). Produção de milho. Guaíba: Agropecuária.

Garbuio, F. J. (2006). Alterações químicas do solo, nutrição, produção e qualidade de grãos de milho em função da aplicação de gesso em sistema plantio direto (Dissertação de Mestrado. Universidade Estadual de Ponta Grossa, Ponta Grossa).

INMET (Instituto Nacional de Meteorologia). (2017). Banco de Dados Meteorológicos para Ensino e Pesquisa. Retrieved from http://www.inmet.gov.br/portal/index.php?r=bdmep/bdmep

Malavolta, E. (2006). Manual de nutrição mineral de plantas. Editora Ceres Ltda.

Malavolta, E., Vitti, G. C., \& Oliveira, A. S. (1997). Avaliação do estado nutricional das plantas: Princípios e aplicações (2nd ed.). Piracicaba, Associacao Brasileira para Pesquisa da Potassa e do Fosfato.

Martinez, H. E. P., Carvalho, J. G., \& Souza, R. B. (1999). Diagnose foliar. In A. C. Ribeiro, P. T. G. Guimarães, \& V. V. H. Alvarez (Eds.), Recomendações para o uso de corretivos e fertilizantes em Minas Gerais, $5^{a}$ Aproximação. Viçosa, Comissão de Fertilidade do Solo do Estado de Minas Gerais.

Maschietto, E. H. G. (2009). Gesso agrícola na produção de milho e soja em solo de alta fertilidade e baixa acidez em subsuperficie em plantio direto (Dissertação de Mestrado, Universidade Estadual de Ponta Grossa, Ponta Grossa).

Oliveira, E. L., \& Pavan, M. A. (1996). Control of soil acidity in notillage system for soybean production. Soil Till. Res., 38, 47-57. https://doi.org/10.1016/0167-1987(96)01021-5

Pereira, F. R. (2007). Gesso de minério associado a fontes de fósforo na cultura do milho em sistema plantio direto no estado de alagoas (Dissertação de Mestrado, Faculdade de Ciências Agronômicas da UNESP, Botucatu).

Prado, R. M. (2008). Nutrição de plantas. São Paulo: Editora UNESP.

Raij, B. V. (1988). Gesso agrícola na melhoria do ambiente radicular no subsolo. São Paulo: Associação Nacional para Difusão de Adubos e Corretivos Agrícolas. 
Rampim, L., Lana, M., Frandoloso, J. F., \& Fontaniva, S. (2011). Atributos químicos de solo e resposta do trigo e da soja ao gesso em sistema semeadura direta. Revista Brasileira de Ciência de Solo, 35, 1687-1698. https://doi.org/10.1590/S0100-06832011000500023

Resende, J. C. F., Bustamante, M. M. C., Markewitz, D., Klink, C. A., \& Davidson, E. A. (2011). Phosphorus cycling in a small watershed in the Brazilian Cerrado: Impacts of frequent burning. Biogeochemistry, 105, 105-118. https://doi.org/10.1007/s10533-010-9531-5

Ritchey, K. D., Silva, S. E., \& Costa, V. F. (1982). Calcium deficiency in clayey B horizons of savannah Oxisols. Soil Science, 133, 378-382. https://doi.org/10.1097/00010694-198206000-00007

Rosolem, C. A., \& Marcello, C. S. (1998). Crescimento radicular e nutrição mineral da soja em função da calagem e adubação fosfatada. Scientia Agrícola, 55, 448-455. https://doi.org/10.1590/S0103-90161998 000300013

Silva, F. A. Z., \& Azevedo, C. A. V. (2016). The Assistat Software Version 7.7 and its use in the analysis of experimental data. African Journal of Agricultural Research, 39, 3733-3740.

Soares, G. F. (2016). Gesso e fósforo na sucessão soja/milho safrinha (Dissertação de Mestrado, Universidade Federal de Goiás, Jataí).

Sousa, D. M. G, Lobato, E., \& Rein, T. A. (2005). Uso de gesso agrícola nos solos do cerrado (2nd ed.). Brasília: Embrapa Cerrados.

Sousa, D. M. G., \& Lobato, E. (2004). Cerrado, correção do solo e adubação (2nd ed.). Brasília: Embrapa.

Zandoná, R. R., Beutler, A. N., Burg, G. M., Barreto, C. F., \& Schmidt, M. R. (2015). Gesso e calcário aumentam a produtividade e amenizam o efeito do déficit hídrico em milho e soja. Pesquisa Agropecuária Tropical, 45, 128-137. https://doi.org/10.1590/1983-40632015v4530301

\section{Copyrights}

Copyright for this article is retained by the author(s), with first publication rights granted to the journal.

This is an open-access article distributed under the terms and conditions of the Creative Commons Attribution license (http://creativecommons.org/licenses/by/4.0/). 